\title{
The Problem of Nationalism in the Early Reformation*
}

\author{
TOM SCOTT \\ University of St Andrews
}

\begin{abstract}
Historians frequently dismiss any use of the term nationalism in the pre-modern period as conceptually illegitimate. In the early Reformation in Germany, the welter of confusing and competing terms to describe Luther's audience - "nation," "tongue," "fatherland," patria-appears to confirm that scepticism. At a regional level, however, where the descriptor Land lacks a precise English equivalent, a consciousness of local identity with undeniable "nationalist" connotations can be discerned, especially in the South-West borderlands with francophone areas. Yet this selfperception sits uneasily with comparable manifestations in Switzerland, where identity was not shaped agonistically over against "foreigners," but was instead deployed by Zwingli and Bullinger to affirm a heroic past epitomized by valiant defence of true religion.
\end{abstract}

Dans leurs études sur les périodes prémodernes, les historiens mettent le plus souvent de côté le terme "nationalisme", jugé anachronique. Dans les débuts de la Réforme en Allemagne, une panoplie d'expressions déroutantes et concurrentes décrivait le public de Luther - "nation ", "langue ", "patrie ", "pays" -, ce qui semble confirmer cette réticence. Toutefois, au niveau régional, alors que l'Anglais ne possède pas d'équivalent précis pour le terme "Land", on discerne une véritable conscience identitaire locale, aux connotations nationalistes indéniables, en particulier pour ce qui est des régions frontalières francophones $d u$ sud-ouest. Cependant, cette auto-perception se compare difficilement avec des phénomènes similaires observables en Suisse, où ce type d'identité ne s'est pas construit de façon agonistique en opposition à l'étranger, mais plutôt, sous l'égide de Zwingli et de Bullinger, afin d'établir un passé hérö̈que marqué par la défense de la vraie religion.

One of the besetting problems in German Reformation scholarship remains the relationship between Martin Luther and his audience. Was Luther-the first proposition-the beneficiary of the growth of a German national identity, and if so, who created it, or did he rather-the second proposition-through his writings, the exploitation of the new print technology, his conscious appeal to the German people, and his translation of the Bible into German first create that national identity? Forty years ago, Geoffrey Dickens could blithely speak of

\footnotetext{
* Expanded version of my remarks in the roundtable discussion "New Approaches to the Early German Reformation" at Sixteenth Century Society and Conference, Vancouver, October 2015. I am grateful to Peter Matheson and Duncan Hardy for their comments on this article.
} 
those German humanists who helped "stir up a German nationalism which was predominantly anti-Italian and anti-papal"1 (as if nationalism at that time was a self-explanatory category). A decade later, Sir Geoffrey Elton described Luther, somewhat dismissively, as merely the reformer of the German lands-"das ist wohl Ehre genug" ${ }^{2}$-as if his message had no resonance for non-Germans.

The notion of Luther as champion of specifically national concerns, although not without foundation, has recently come under attack from several directions. Georg Schmidt, in pointing out that Luther desired a purified and self-reliant German national church (rather than a series of territory- or citybased churches), did not deny that Luther's framework-one might say his field of vision-remained that of the empire rather than some conjectural "German nation." ${ }^{3}$ Caspar Hirschi has gone further in declaring that, for Luther, German national honour was an alien concept and that the German focus of his writings in no sense implied that he regarded the Germans as a chosen people. ${ }^{4}$

In the title of his famous tract of 1520, An Address to the Christian Nobility of the German Nation Concerning the Reform of the Christian Estate, Luther was merely echoing the fact that by the end of the fifteenth century the "Holy Roman Empire" as a polity had become indissolubly linked to the "German nation" - the latter term first encountered in the vernacular as early as $1446,{ }^{5}$ though it did not become common currency until the following century. This conjugation gave considerable scope for conceptual imprecision, which may have been deliberate.

\section{A. G. Dickens, The German Nation and Martin Luther (London: Edward Arnold, 1974), 1.}

2. G. R. Elton, "Die europäische Reformation. Mit oder ohne Luther?" in Elton's Studies in Tudor and Stuart Politics and Government, IV: Papers and Reviews 1983-1990 (Cambridge: Cambridge University Press, 1992), 246-63, 262. Originally in Martin Luther: Probleme seiner Zeit, ed. Volker Press and Dieter Stievermann, Spätmittelalter und Frühe Neuzeit: Tübinger Beiträge zur Geschichtsforschung 16 (Stuttgart: Klett-Cotta, 1986), 43-57.

3. Georg Schmidt, "Luther und die frühe Reformation - ein nationales Ereignis?," in Die frühe Reformation in Deutschland als Umbruch, ed. Bernd Moeller and Stephen E. Buckwalter, Schriften des Vereins für Reformationsgeschichte 199 (Gütersloh: Gütersloher Verlagshaus, 1998), 54-75, 54 and 68.

4. Caspar Hirschi, Wettkampf der Nationen. Konstruktionen einer deutschen Ehrgemeinschaft an der Wende vom Mittelalter zur Neuzeit (Göttingen: Wallstein, 2005), 417: "Die nationale Ehre bedeutete ihm so gut wie nichts."

5. Rüdiger Schnell, "Deutsche Literatur und deutsches Nationalbewußtsein in Spätmittelalter und Früher Neuzeit," in Ansätze und Diskontinuität deutscher Staatsbildung im Mittelalter, ed. Joachim Ehlers, Nationes: Historische und philologische Untersuchungen zur Entstehung der europäischen Nationen im Mittelalter 8 (Sigmaringen: Jan Thorbecke, 1989), 247-319, 255n31. 
Ulrich Nonn, for instance, has observed that the linkage did not necessarily imply that all members of the "German nation" were in fact linguistically "German." Who or what constituted the "German nation" was the stuff of learned debate which stretched well back into the Middle Ages; it has recently been exhaustively examined by Len Scales, whose account, however, stops in $1414 .^{7}$ Yet it was the debates of the fifteenth century and the increasing use of the term in the proceedings of the imperial diets that furnished the context for arguments lent new urgency in the early Reformation. The following remarks, therefore, are intended as a modest attempt amid the welter of literature to clarify the terms used, without implying that definitions of "Germany" and "nation," let alone "nationalism," are only valid if their meaning is unambiguous. ${ }^{8}$ I am chiefly concerned to investigate the first proposition, but my concluding remarks will suggest that even the second is not entirely straightforward.

In ideological terms the use of "nationalism" in accounting for Luther's appeal suffers from a threefold handicap: professional, conceptual, and evidential. For historians in post-war Germany, nationalism has always been an uncomfortable topic. It lies too close to the discredited triumphalism of nineteenth-century Protestantism as the driving force of German unification, not to speak of the horrors of National Socialism in the twentieth. Within the wider scholarly community, the prevailing social-democratic consensus regards nationalism as a pathogen on the body politic-essentially reactionary, and, especially on the Left-as embodying a false consciousness which seeks to elide or conceal social and economic conflicts that are grounded in class antagonisms. More broadly, studies of modern nationalism regard it as an ideological construct-a view that for all their differences unites Benedict Anderson, Ernst Gellner, and Eric Hobsbawm - which only emerged with the rise of nation states and the creation of a public discourse that shaped individual and collective identities. Analysis

6. Ulrich Nonn, "Heiliges Römisches Reich Deutscher Nation. Zum Nationen-Begriff im 15. Jahrhundert," Zeitschrift für historische Forschung 9 (1982): 129-42, 142.

7. L. E. Scales, The Shaping of German Identity: Authority and Crisis, 1245-1414 (Cambridge: Cambridge University Press, 2012).

8. The notes are accordingly kept to a minimum. For fuller references see Hirschi and Schnell, and for the medieval centuries in general, Scales. 
of modern nationalism therefore discounts any anterior manifestations as categorically inadmissible, a stance abetted by medievalists' own rejection of the concept in favour of the notion of an ostensibly unideological "national consciousness." That links between the two can nevertheless be posited has been suggested by Hirschi, though his argument is not germane to our present argument. ${ }^{10}$

A further reluctance to deploy nationalism as a breeding-ground for Luther's enthusiastic reception has lain in its singular appropriation by East German historians as a driving force of the "early bourgeois revolution," the overarching theoretical construct whereby the Reformation and the German Peasants' War were seen as a struggle to create a German nation state. ${ }^{11}$ The original proponent of this theory, Max Steinmetz, was perhaps more wedded to its nationalist aspect than other East German colleagues who preferred to focus on early capitalism. ${ }^{12}$ Although the early bourgeois revolution has disappeared alongside the state that spawned it, it should be recorded that the theory identified strands of political, economic, social, and cultural dislocation which clearly reflected a wider malaise in German affairs, even if the conceptual linkage was exposed as resting upon shaky foundations, quite apart from the lack of any empirical underpinning. ${ }^{13}$

If as a working hypothesis we can accept that Nationalbewußtsein is a more accurate descriptor than nationalism in our period, the term still requires

9. Hirschi, 23-30, 34-44. But see the brisk revisionism of Rees Davies, who argues that medievalists are perfectly entitled to use the term "nationalism," provided that they define what they mean. R. R. Davies, "Nations and National Identities in the Medieval World: An Apologia," Revue Belge d'Histoire Contemporaine 34 (2004): 567-79. I am indebted to Duncan Hardy for this reference.

10. He contends that the German humanists' development of a collective discourse was fundamental to the evolution of modern nationalism. Hirschi, 320.

11. Dieter Mertens, “Nation als Teilhabeverheißung: Reformation und Bauernkrieg," in Föderative Nation. Deutschlandkonzepte von der Reformation bis zum Ersten Weltkrieg, ed. Dieter Langewiesche and Georg Schmidt (Munich: Oldenbourg, 2000), 115-34, 115.

12. Mertens, "Nation als Teilhabeverheißung," 131.

13. For a collection of essays on the early bourgeois revolution see Rainer Wohlfeil, ed., Reformation oder frühbürgerliche Revolution? Nymphenburger Texte zur Wissenschaft 5 (Munich: Nymphenburger Verl.-Handlung, 1972). 
elucidation. There is widespread agreement that natio was rendered in the vernacular as gezung (tongue)-a linguistic category..$^{14}$ But gezung was more than language: it implied a cultural identity, embodying what Hirschi calls "sacred traditions." ${ }^{15}$ In the "nations" of the medieval universities, however, students might often be bundled together under the label "German" even when they were neither linguistically nor ethnically German. In his Address to the Christian Nobility, Luther certainly did not have these "nations" in mind, nor was he invoking the term nation as it was used at councils of the church. ${ }^{16}$

Rüdiger Schnell has made the interesting observation that for medieval authors the ancient perception of boundaries as being defined by rivers, mountains, or forests was increasingly replaced by linguistic divisions, though tellingly that held good for German writers and seems not to have occurred in Romance areas. ${ }^{17}$ The culturally connoted use of the German language is especially visible in the controversy over the correct assignation of Alsace (was it Gallia or Germania?) and became acute at the time of the Burgundian Wars between 1475 and 1477, when the struggle against Duke Charles the Bold by the Swiss and the south-west German imperial cities came to be seen as a conflict that affected all Germans (Tútschen, those of German tongue) in the face of welsch aggression, in other words, "foreignness" linguistically defined. ${ }^{18}$ Frontier cities such as Montbéliard illustrate the point: given its loyalty to the "German nation" situated on the linguistic frontier to Welschland, Bern pressed for the city to be admitted to the Swiss Confederation as an associated member. ${ }^{19}$ To these observations I will return.

This underscores a fundamental feature of German "nationalism": it was constructed "agonistically," as Hirschi puts it, that is to say, in a series of

\section{Hirschi, 158.}

15. Hirschi, 72.

16. Thomas Kaufmann, An den christlichen Adel deutscher Nation von des christlichen Standes Besserung, Kommentare zu Schriften Luthers 3 (Tübingen: Mohr Siebeck, 2014), 50.

17. Schnell, 268-70, 295.

18. Claudius Sieber-Lehmann, Spätmittelalterlicher Nationalismus. Die Burgunderkriege am Oberrhein und in der Eidgenossenschaft, Veröffentlichungen des Max-Planck-Instituts für Geschichte 116 (Göttingen: Vandenhoeck \& Ruprecht, 1995), 401. He concedes that the concept of the "linguistic nation" has been challenged in the light of the experience of nationalism in developing countries (406). 19. Sieber-Lehmann, 116-17, 126. Only in the wake of the Burgundian Wars did the Confederation acquire francophone members. 
Feindbilder. ${ }^{20}$ That is why he prefers to speak of a Nationaldiskurs, rather than a Nationalbewußtsein. This discourse over national identity can be traced back to the Greeks, but in Germany it was only in the generation before the Reformation that these hostile images took on an explicitly racial cast, as the retrieval of a heroic German past allowed avowedly "nationalist" humanists such as Conrad Celtis to exalt the Germans above their supposedly racial inferiors, such as the Slavs ${ }^{21}$ (or subsequently, in Luther's case, the Wends, who had permission to reside in Wittenberg only in the suburbs). ${ }^{22}$ That went well beyond what humanists in general had earlier believed: those who belonged to the nation, as Dieter Mertens has argued, were those who subscribed to the "competition" between nations in the context of education, aesthetics, and culture, which of course excluded the bulk of the population, which remained unlettered. ${ }^{23}$

The role of humanists in Germany in forging a sense of pride, honour, and dignity among those previously regarded as uncouth, primitive, or barbarianwhich would allow Germans to stand alongside, or supersede, other cultural nations-remains deeply ambivalent. An intellectual elite, sustained by international contacts and friendships, writing almost exclusively in Latin, might at times invoke the German fatherland, but what did they understand by fatherland ${ }^{24}$ These men had little interest in the German language as a mark of prestige or antiquity; they did not question the superiority of the ancient languages, and Latin was the template by which the honour and cultural

20. Hirschi, 258-301; Mertens, "Nation als Teilhabeverheißung," 125.

21. Tom Scott, "The Early Reformation in Germany between Deconstruction and Reconstruction," in Scott's The Early Reformation in Germany: Between Secular Impact and Radical Vision (Farnham and Burlington, VT: Ashgate, 2013), 7-30, 21, citing Conrad Celtis, "An Ode Delivered Publicly in the University of Ingolstadt," in The Northern Renaissance, ed. and trans. Lewis W. Spitz (Englewood Cliffs, NJ: Prentice Hall, 1972) 15-27, 19. See also Hirschi, 370-71.

22. Lyndal Roper, Martin Luther: Renegade and Prophet (London: The Bodley Head, 2016), 79.

23. Dieter Mertens, "Deutsche Nationalgeschichte um 1500. Soziale, formale und materielle Konstituenten," in Historiographie - Traditionsbildung, Identitätsstiftung und Raum. Südwestdeutschland als europäische Region, ed. Sönke Lorenz, Sabine Holtz, and Jürgen Michael Schmidt, Schriften zur südwestdeutschen Landeskunde 71 (Ostfildern: Jan Thorbecke, 2011), 1-19, 15.

24. Hirschi, 42. 
achievement of all nations was to be measured. ${ }^{25}$ These humanists made little effort to appeal to the population at large; ${ }^{26}$ it is hard to know what impact the rediscovery of Tacitus's Germania had beyond their own circle. What can be said is that long before the late fifteenth century there was widespread dismay at how few sources on German history were available, aside from Tacitus. ${ }^{27}$

Yet after 1500 there is evidence of a shift. In 1505, the Alsatian humanist Jakob Wimpfeling composed his Epitome rerum Germanicum, in effect the first history of Germany written by a German, albeit in Latin. In it he divided the Germans, following classical authors, into genera (Stämme, tribes) who, he declared, were collectively able to withstand the looming Turkish menacebut he did not subsume them under a single German "nation." ${ }^{28}$ With Ulrich von Hutten, however, the commitment to a campaign that openly championed German national interests became unmistakable. A former monk from a family of Franconian knights, Hutten led a vagabond existence, briefly studying at universities in Germany and Italy, only coming to prominence with his defence of the Hebraist Johannes Reuchlin against the Dominicans of Cologne in his Letters of Obscure Men. In 1517, he was crowned imperial poet laureate by Maximilian (like Celtis before him in 1495, and Heinrich Bebel in 1501), and two years later published his most savage satire on ecclesiastical corruption and the power of the papacy, Vadiscus sive trias Romana. He had already exhorted the Germans as a nation to rise up against the Turks, and in Vadiscus he explicitly invoked German freedom, referring to "our fatherland of the German nation.." ${ }^{29}$ More tellingly, around 1520 he turned from Latin to writing in German in order to render his message intelligible to a wider audience. ${ }^{30}$ Hirschi claims, with some justice, that Hutten was the only humanist who chose to address the population at large, ${ }^{31}$ the problem is to know whether his change

\section{Hirschi, 269.}

26. Hirschi, 257.

27. Schnell, 318.

28. Mertens, "Deutsche Nationalgeschichte," 10. The Epitome did not first appear as an autograph but as part of a collection edited by Thomas Wolf, Jr. (1n1).

29. Hirschi, 414; Günter Vogler, "Reichsvorstellungen im Umkreis des Bauernkriegs", in Alternativen zur Reichsverfassung in der Frühen Neuzeit, ed. Volker Press and Dieter Stievermann, Schriften des Historischen Kollegs: Kolloquien 23 (Munich: Oldenbourg, 1995), 23-41, 27.

30. Schnell, 257.

31. Hirschi, 375. 
of tack broadened the audience for Luther's message, or whether Luther's own striking propaganda tracts of 1520 had created an audience upon which Hutten could capitalize. It is at least arguable that Hutten's subsequent involvement in the so-called Knights' Revolt led by Franz von Sickingen, intended to achieve a reform of the empire by the nobles and cities against the princes and prelates, was unlikely to have occurred unless he had already been inspired by Luther (whose aims in any case he misunderstood). Hutten, moreover, neatly illustrates a conceptual dilemma. He invoked the "German fatherland of the German nation," but that invocation only had substance and direction in the context of imperial reform. Hirschi's view that "Empire" and "fatherland" had no connection except via the bridge of "nation" may well be correct, ${ }^{32}$ but it threatens to separate categories whose boundaries, as he argues elsewhere, were becoming increasingly blurred.

That the terms "nation," "fatherland," or patria were polysemic and ideologically freighted became apparent during the reign of Emperor Maximilian. The monarch frequently invoked the "German nation," by which he meant his constitutional counterparts, the Estates of the Empire, in what Peter Moraw has dubbed the dualism of König und Reich. ${ }^{33}$ But when he posed as defender of the "honour" of the German nation he was in reality soliciting support for campaigns, under an imperial banner, that were Habsburg dynastic ventures in disguise. Maximilian would not have thought, unlike the humanists, of linking "nation" to "fatherland"; indeed, his concerns were far removed from any ideologically tinged "nationalism." ${ }^{34}$ Yet after his death, the question of his succession raised fears among the electors that a non-German might be crowned emperor which, as Archbishop Albrecht of Mainz declared, might lead to a revolt (Bundschuh) of the common man. ${ }^{35}$ In the end, the choice fell

32. Hirschi, 43.

33. Peter Moraw, "Bestehende, fehlende und heranwachsende Voraussetzungen des deutschen Nationalbewußtseins im späten Mittelalter," in Ehlers, ed., 99-120, 118; Peter Moraw, Von offener Verfassung zu gestalteter Verdichtung. Das Reich im späten Mittelalter, Propyläen Geschichte Deutschlands, 3 (Frankfurt am Main and Berlin: Propyläen, 1989).

34. Hirschi, 172.

35. Hirschi, 400. 
on Charles V who was in no useful sense of the word a German but who, by inheritance, could don the mantle of a German patriot.

What associations, therefore, did the term "fatherland" arouse within Germany? Hirschi has insisted that patria and Vaterland were not synonymous, for the former comes closer to our present understanding of the term Heimat. ${ }^{36}$ Yet he goes on to argue that the German humanists were conscious of having many "fatherlands", from town or city upwards. He instances Jakob Wimpfeling, who saw himself as a son of Sélestat, a native of Alsace, and a member of the German nation. ${ }^{37}$ In other words, patria depended on context and audience, but essentially it was built up in layers from locality to nation, each layer containing, not cancelling, the other, in the manner of a Russian doll. Mertens also sees patria as small-dimensioned: people thought from part to whole, from region to nation, from close experience to imagined community. ${ }^{38}$

This brings us to an issue that has been much discussed in recent historiography, namely, whether a sense of national consciousness was not in fact located in the Land, a term which has no direct translation in English, but which approximates to the French pays. Alas, Landesbewußtsein is as controversial a term as Nationalbewußtsein, and for much the same reasons. Observing that the terms Land and Landschaft are themselves ambiguous, Klaus Graf has sought to replace, echoing comments voiced above, Landesbewußtsein with Landesdiskurs - for what constituted a Land was open to varying interpretations. ${ }^{39}$ Dieter Mertens observes that the rise of regional history (Landesgeschichte) in the nineteenth century was, despite the name, an attempt to forge a German national identity, though it contained the obvious danger of encouraging particularism rather than unity. ${ }^{40}$ Nor is the problem

\section{Hirschi, 42; Schnell, 259.}

37. Hirschi, $81,110-11$.

38. Mertens, "Nation als Teilhabeverheißung," 123. He also understands patria as a legal category as much as a socio-cultural one (117).

39. Klaus Graf, "Aspekte zum Regionalismus in Schwaben und am Oberrhein im Spätmittelalter," in Historiographie am Oberrhein im späten Mittelalter und in der frühen Neuzeit, ed. Kurt Andermann, Oberrheinische Studien 7 (Sigmaringen: Jan Thorbecke, 1988), 165-92, 169. Graf's essay is more concerned with the origins and character of Landesherrschaft, which lies beyond the scope of the present remarks.

40. Dieter Mertens, “'Landesbewußtsein' am Oberrhein zur Zeit des Humanismus”, in Die Habsburger im deutschen Südwesten. Neue Forschungen zur Geschichte Vorderösterreichs, ed. Franz Quarthal and 
solved by recourse to the term "regionalism," which contains its own structural determinants and cannot easily be integrated into a "discourse." difficult in English to avoid the term "region" as a simple descriptor, given that there is no accepted translation for Land. ${ }^{42}$

Graf has investigated Swabia, which the humanist Heinrich Bebel, former professor of poetry at Tübingen, described as his "fatherland." But Swabia might appear elsewhere as a "nation," as in 1493 when Heilbronn and Wimpfen wrote to the cities of the Swabian League to assure the latter of their commitment to further the honour of the "common Swabian nation." Did this imply, asks Graf, that the Swabian nation was a political association, or a defined community, or a polity embodying certain values? ${ }^{43}$ To make matters worse, the Alsatian humanist Beatus Rhenanus could write of suevorum nationes in the plural! ${ }^{44}$ There was no consensus, moreover, where the frontiers of the region lay. The nobles of the Kraichgau, Graf notes, refused to join the Swabian League because they claimed to be Rhinelanders, not Swabians. ${ }^{45}$ Yet Johannes Nauclerus, the historiographer of the dukes of Württemberg and co-founder of the University of Tübingen, who spoke only in terms of patria, not of natio, regarded Swabia

Gerhard Faix (Stuttgart: Jan Thorbecke, 2000), 199-216, 200-01.

41. See the remarks in Dieter Mertens, "Region und Universalität im oberrheinischen Humanismus," in Räume und Grenzen am Oberrhein, ed. Brigitte Herrbach-Schmidt and Hansmartin Schwarzmaier, Oberrheinische Studien 30 (Ostfildern: Jan Thorbecke, 2012), 139-56.

42. It is at this point that Rees Davies's arguments for a medieval "nationalism," predicated upon the close relationship in the Middle Ages between the English crown and the English nation, break down in the German context, for the political-cultural framework of the German polity was vested in the Reich, whose monarch was not, and never claimed to be, "national."

Davies, 572 ff.

43. Klaus Graf, “Das 'Land' Schwaben im späten Mittelalter," in Regionale Identität und soziale Gruppen im deutschen Mittelalter (Zeitschrift für historische Forschung, Beiheft 14), ed. Peter Moraw (Berlin: Duncker and Humblot 1992), 127-64, 130: they would support "was den erbern stetten auch gemeiner swebischen nacion zu eren, nutz und gut dienen mocht." See also Klaus Graf, "Souabe. Identité régionale à la fin du Moyen Âge et à l'époque moderne," in Identité régionale et conscience nationale en France et en Allemagne du Moyen Âge à l'époque moderne (Francia. Forschungen zur westeuropäischen Geschichte, Beiheft 39), ed. Rainer Babel (Sigmaringen: Jan Thorbecke 1997), 293-303.

44. Mertens, "Landesbewußtsein," 214.

45. Graf, “'Land' Schwaben,” 136-38. 
as embracing not only the Kraichgau but the Breisgau, and, beyond the Rhine, the Thurgau and Alsace as well. ${ }^{46}$

And it is Alsace that offers the most instructive example of terminological confusion-or disagreement-among the German humanists. The controversy over whether Alsace on the left bank of the Rhine was "German" stretched well back into the Middle Ages. ${ }^{47}$ Many authors accepted the distinction between Germania and Gallia, but insisted that the latter on grounds of language and culture should properly be regarded as "German." This was certainly the view of Jakob Wimpfeling, whose eponymous tract Germania dealt essentially with Alsace. ${ }^{48}$ But it was not shared by his fellow-native of Sélestat, Rhenanus, who not only poured scorn on the equation of German blood with German freedom and the valiant defence of German honour, but drew the frontiers of "Germany" very narrowly, excluding both the left bank of the Rhine and the right bank of the Danube; indeed, these areas, he contended, had not been in German hands even before the Roman conquest. All he was prepared to concede was that Alsace had become part of "Germany" through acculturation. ${ }^{49}$

For our enquiry, the significance of Alsace went much further than its cultural identity. The western borderlands of the empire from the late fourteenth century onwards had been the battleground between Germans and welsch, with the irruptions of the Armagnac mercenaries in the 1440s marking a new phase of intensity. ${ }^{50}$ Then came the mortgaging of Alsace and other Austrian places on the Upper Rhine by Archduke Sigismund to Duke Charles the Bold of Burgundy in 1469, in the wake of which the duke's governor, Peter von Hagenbach, himself a south Alsatian frontalier, imposed a harsh regime which was only terminated by his execution after a show trial in Breisach in 1474 .

The Burgundian Wars that followed ensured that the lands on the Upper Rhine remained unsettled, while Maximilian's campaigns into Burgundy in the 1510s only strengthened the perception of the French as inveterate enemies of the Germans. In short, ordinary folk cannot have been ignorant of the linguistic

46. Mertens, "Landesbewußtsein," 204-05.

47. Schnell, 262-75, with extensive bibliographical references.

48. Mertens, “Landesbewußtsein,” 206. On Wimpfeling's controversy with Thomas Murner (who insisted that Strasbourg and Alsace were French) see Francis Rapp, "Autour de l'identité régionale Alsacienne au Moyen Âge," in Babel, ed. 281-92, 291.

49. Hirschi, 454-55; compare Mertens, “Landesbewußtsein,” 214.

50. Rapp, 288-89. 
divide and political antagonism, which contributed to an inchoate sense of nationalism by means of Feindbilder. The Upper Rhine was a densely populated region, where levels of literacy, thanks to the many cities and their schools, can be presumed to have been high. Moreover, since much of the Upper Rhine fell within the bounds of Outer Austria, it remained a region "near to the king" (in Moraw's diction), that is to say, the involvement in and knowledge of imperial politics on the part of its inhabitants must have been considerable. And certain humanists took that as their cue to stress the Habsburgs' connection to the region, for both Jakob Mennel, Maximilian's historiographer royal, and Hieronymus Gebwiler, director of the famous humanist library in Sélestat, declared the Upper Rhine to be the birthplace of the Habsburg dynasty ${ }^{51}-$ which, after all, was only perpetrating a minor geographical sleight-of-hand.

We are entitled to say, therefore, that elements of a German national consciousness did manifest themselves in the region before the Reformation, and that it would have encouraged receptivity for aspects of Luther's messagealbeit transmitted by men such as Martin Bucer and Huldrych Zwingli, citybased Reformers of humanist upbringing, who soon developed a more radical evangelical theology, Reformed Protestantism as it came to be known, which alienated them from Luther, though the differences were not immediately apparent. ${ }^{52}$

Yet there is a fly in the ointment. The Upper Rhine bordered the Swiss Confederation, and it was precisely in these years that the Swiss and "Swabians" (that is, south Germans in general) were growing apart, despite a common language, socio-economic connections, and family ties, as each side engaged in a war of vituperative and scatological name-calling, in which the

\section{Mertens, “Landesbewußtsein,” 216.}

52. One illustration is provided by Herman von dem Busche, a Cologne humanist who in 1521 published a pamphlet entitled The Passion of the Blessed Martin Luther, or his Sufferings which came close to equating Luther with Christ (Roper, 191-92), but who the following spring could be found sharing a meal in a house in Basel alongside several clerics and the firebrand Hans Murer, known as Karsthans, who was too radical in his advocacy of rebellion even for Zwingli, as they defied the Lenten fasting provisions by devouring a suckling-pig. Tom Scott, "From the Bundschuh to the Peasants' War: From Revolutionary Conspiracy to the Revolution of the Common Man," in Scott's Town, Country, and Regions in Reformation Germany, Studies in Medieval and Reformation Traditions 106 (Leiden and Boston, MA: Brill, 2005), 125-48, 134-35. 
"sow-Swabians" were pitched against the "cow-Swiss"" ${ }^{3}$ This estrangement led, in the aftermath of the Swiss War of 1499 (which bore traces of a civil war across the Rhine), to the de facto withdrawal of the Swiss from the dayto-day affairs of the empire (though not to their severance from the empire as a salvific and juridical community). Nevertheless, the Swiss were regarded as dishonourable, as apostates rather than as foreigners, since they had been lured by avarice into mercenary service in the armies of Germany's enemies. The humanists even coined a mockingly ambiguous term for the Swiss: deutsche Welschen or semigalli. ${ }^{54}$ The implications for the reception of the Reformation in Switzerland as the outflow of "national" sentiment will be considered below.

Let us draw these strands together. It should be obvious that "nationalism" in Germany on the eve of the Reformation could manifest itself in different guises, in different circumstances, and with different aims. Much of the grievance literature of the fifteenth century, from the ecclesiastical hierarchy's Grievances of the German Nation (its criticism of the papacy and the practices of its agents in the German lands) downwards to more mundane local and secular concerns ${ }^{55}$ carried through into Luther's attack on Rome, not simply his theological disqualification of papal authority but also his description of secular abuses stemming therefrom, as can be seen in the concluding section of the Address to the Christian Nobility of the German Nation. ${ }^{56}$ One example may suffice.

From the mid-fifteenth century onwards, beginning with the heated correspondence aroused by Enea Silvio Piccolomini's defence of papal prerogatives in his tract Germania of 1457, the grievances of the German church (expressed as the "German nation") excoriated the papacy's ever-increasing

53. Helmut Maurer, Schweizer und Schwaben, Ihre Begegnung und ihr Auseinanderleben am Bodensee im Spätmittelalter, 2nd edn, Konstanzer Universitätsreden 136 (Konstanz: Universitätsverlag, 1991).

54. Hirschi, 299.

55. For a selection of documents in translation see Gerald Strauss, ed., Manifestations of Discontent in Germany on the Eve of the Reformation (Bloomington, IN/London: Indiana University Press, 1971).

56. $\$ 26$ of the tract was renumbered $\$ 27$ in the second edition after the insertion of a new section that affirmed Luther's recognition of the validity of the empire despite his rejection of the translatio imperii. Much of $\$ 26$ reiterates themes already broached in his Sermon on Good Works. Kaufmann, 462, 481. 
demands for payments, which were sucking gold and silver out of Germany. This rapacity became a matter of public debate, which broadened to involve the lower clergy and urban layfolk, ${ }^{57}$ and fed directly into the controversy over the selling of indulgences. The grievances were presented afresh in 1521 at the same diet of Worms that condemned Luther, whose initial attack had been on indulgences $!^{58}$ Before that date, the anonymous Revolutionary of the Upper Rhine had already urged the emperor to supervise ecclesiastical appointments since the purchase of clerical office-in itself a scandal-was draining specie from Germany to Rome. ${ }^{59}$ In the early Reformation years, the theme was taken up not only by Luther but also by Johann Eberlin von Günzburg, in the first of whose Fifteen Confederates of 1521 the friars were condemned for accumulating untold riches: the Observants were raking in 200,000 $\mathrm{fl}$ a year, and the four mendicant orders as a whole over 1 million fl from the German nation. "Then," he continued, "what should I say about the papal see which annually relieves the German nation of 300,000 fl?" 60 Hirschi has pointed out, however, that in comparison with France, Italy, or Spain, Germany (or the empire) got off lightly, remitting to the curia a fraction of what other nations did. ${ }^{61}$

These and similar abuses were perceived as an affront to the "Christian people of the German nation,"62 as Eberlin's tract put it, but invariably they were articulated in the context of imperial reform, which did not invoke a specifically "national" agenda. It applied also to the grievances voiced during the German Peasants' War. Friedrich Weygandt's draft of an "imperial Reformation” of May 1525, intended for discussion at the so-called peasants' parliament at Heilbronn that month, was exactly what it set out to be: a detailed blueprint for political, legal, social, and economic reform of the empire. ${ }^{63}$ It made no

\section{Hirschi, 143.}

58. Texts in Strauss, ed., 38, 43, 50, 51, 55, 56, 57.

59. Klaus H. Lauterbach, ed., Der Oberrheinische Revolutionär. Das buchli der hundert capiteln mit xxxx statuten (Monumenta Germaniae Historica: Staatsschriften des späteren Mittelalters, 7) (Hannover: Hahnsche Buchhandlung, 2009), 335, 430.

60. Geoffrey Dipple, ed., The Fifteen Confederates [of] Johann Eberlin von Günzburg (Cambridge: James Clarke, 2014), 27.

61. Hirschi, 144.

62. Dipple, 22.

63. Klaus Arnold, “damit der arm man vnnd gemainer nutz iren furgang haben ... Zum deutschen 'Bauernkrieg' als politische Bewegung: Wendel Hiplers und Friedrich Weygandts Pläne von einer 
reference whatsoever to the "German nation." Nor can any "national" agenda be discerned among the peasants' grievances more generally: the Stühlingen rebels in mid-1524, having received no satisfaction, demanded a hearing before the imperial court of chancery the following spring, in the hope that it would override the authority of the local feudal lords. ${ }^{64}$

With all due caution, therefore, it seems to me legitimate to discern elements of a Nationalbewußtsein in Germany on the eve of the Reformation that undoubtedly helped create a favourable climate for the reception of Luther's message, provided that we at the same time recognize that it was the very ambiguity of the terms "German nation," "fatherland," or patria that allowed them to appeal to and serve the interests of an audience that was very far from being a "national" one, let alone nationalist, in any modern sense. ${ }^{65} \mathrm{~A}$ sense of national identity is most readily observable on the Upper Rhine, and it is striking how so many of the humanists Eberlin cites as champions of a German identity before and during the Reformation were natives of that area. ${ }^{66}$ Although Luther understood his message as directed to the entire Christian people (Kirchenvolk) of the German lands, ${ }^{67}$ it is evident that he was heard and received through the filter of local or regional concerns and desires. Here Switzerland provides the most telling contrast.

In Reformed Switzerland, Huldrych Zwingli's religious message directly chimed with his own reading of Swiss identity, valour, and honour. Clearly, given the

'Reformation' des Reichs,' Zeitschrift für historische Forschung 9 (1982): 257-313. Arnold's argument has been treated with scepticism: Mertens, in "Nation als Teilhabeverheißung," regards it as giving comfort to Max Steinmetz's views (131); Vogler is willing to admit some elements of imperial reform in the peasants' programs but insists that they did not stem from the peasants themselves (Vogler, 41). Hirschi (438 and n. 128) insists that the Peasants' War had no "national" content at all, but Arnold never suggested it did. Weygandt's tract is translated in Tom Scott and Bob Scribner, eds., The German Peasants' War: A History in Documents (Atlantic Highlands, NJ: Humanities Press, 1991), 259-64.

64. Scott and Scribner, eds., 65.

65. Hirschi speaks of the "chameleon-like" capacity of the Nationsdiskurs for self-transformation and combination with other discourses (500).

66. Dipple, 23-24. Twelve of the fifteen names mentioned came from the south-west.

67. Mertens, "Nation als Teilhabeverheißung," 128; compare Kaufmann, 50. 
composition of the Swiss Confederation, any deployment of terms such as "nation" or "national discourse" is inappropriate-indeed, inconceivable. But in his Ein gottlich Vermanung of 1522, Zwingli made it very clear that he was championing Swiss patriotism. ${ }^{68}$ The tract, almost an inversion of the tenor of German grievances, lambasted the Swiss for betraying their ancient freedom, which had brought them so many victories from small beginnings, by entering foreign military service as mercenaries; the receipt of money at the hands of foreign powers, moreover, would bring evil customs and fashions into the land, such as luxurious clothing. Here, the Feindbild served not as an agonistic instrument in the construction of a community of honour, but rather as the source of its destruction! In the last sentence of his tract, Zwingli warned the Swiss to beware of foreign lords, for they would bring dishonour upon them. ${ }^{69}$

Ein gottlich Vermanung also served to draw the boundaries of the Confederation not according to language or tradition but by a heroic stylization of Swiss valour in the fifteenth century, which now identified the Rhine as Switzerland's true frontier over against its German or imperial foes whom the Swiss had defeated in $1499 .^{70}$ Zwingli invoked the righteousness of the Old Testament prophets, from whose shining example the Swiss were in danger of deviating if they did not embrace wholeheartedly the evangelical promise of the New Testament. Zwingli's argument, in short, was at once moral and religious as well as political and social: the distinction had been elided. Patriotism and true religion had become synonymous. This view was echoed by the young Heinrich Bullinger (who became Zwingli's successor) in 1528 in his tract Anklag und ernstliches Ermanen, in which the valiant Swiss were described as God's chosen people of Israel, who had repelled enemies far mightier than they. Then he excoriated the military enterprisers ("Kriegsgurgler") of his day who organized mercenary recruitment and on whose profits they lived in the lap of luxury. Yet all the while, Switzerland's natural endowment (described in

68. Huldrych Zwingli, Ein gottlich Vermanung an die eersamen, wysen, erenvesten, eltisten Eidgnossen zنำ Schwytz, daß sy sich vor frömbden Herren hutind und entladind, Huldrichi Zwingli, einveltigen Verkündens des Euangelii Christi Jhesu (Zürich, 1522), in Ulrich Zwingli: Hauptschriften, 7, ed. Fritz Blake, Oskar Farner, and Rudolf Pfister (Zürich: Zwingli-Verlag, 1942), 5-29.

69. Zwingli, 29: "Hüt dich, Schwytz vor frömbden Herren; Sy brächtend dich zů Uneeren.”

70. Zwingli, 28: "Man darff der Letze zu Art und Nefels nüt me, der Rhein ist die Letze." 
paradisiacal terms) should be sufficient to sustain its people, secure within its frontiers of the mountains and the Rhine. ${ }^{71}$

Yet even at this last stage a note of caution should be sounded. Zwingli was addressing a German-speaking audience (as was Bullinger), but before his death on the battlefield of Kappel in 1531, fighting against the Catholic inner cantons, Bern had already sent Guillaume Farel to proselytize throughout the Romandie (the francophone lands on the north shore of Lake Geneva) from 1526 onwards, that is, even before the city itself had formally accepted the Reformation in the wake of the Disputation of January $1528 .^{72}$ In truth, the Reformers' message, whether articulated by Luther, Zwingli, or their successors, knew no (national) boundaries, and under Calvin in Geneva indeed became an international movement.

71. Heinrich Bullinger, Anklag und ernstliches Ermanen Gottes Allmächtigen zuo eyner gemeynenn Eydgnoschafft, das sy sich von jren Sünden zuo jmm keere ... (Zürich, 1528): "Ir bekriegend mir myn armes volck tåglich vnd nemmend über sy Pensionen oder gaaben" (13a); "Daby sehend ir aber tåglich das kriegen nützid dan̄ müssiggenger zücht” (16); “mit dem Ryn vnd dem pirg, das üch wie ein feste ringmur umbfacht vnnd beschlüßt. Das betrachtend yetzung erkennend in was lustgarten vnd Paradies ir sitzend" (39). I am indebted to Robert Bast for drawing my attention to this tract.

72. Bruce Gordon, The Swiss Reformation (Manchester and New York: Manchester University Press, 2002), 149-50. See also Tom Scott, The Swiss and Their Neighbours: Between Accommodation and Aggression, 1460-1560 (Oxford: Oxford University Press, 2017), 111. 
